\title{
What are Production Diseases, and How do We Manage Them?
}

\author{
By Oded Nir (Markusfeld)
}

Veterinary Services and Animal Health, Ministry of Agriculture, Israel.

\begin{abstract}
Nir (Markusfeld) O: What are production diseases, and how do we manage them? Acta vet. scand. 2003. Suppl. 98, 21-32. - The term "Production Diseases" referred traditionally to those diseases induced by management practices, metabolic diseases are typical examples. Recently, the term "Production related diseases" has been enhanced to include other traits, such as infertility, and diseases such as mastitis and lameness that might involve infectious agents but exacerbated by nutritional or managemental factors. The presentation deals with Production Diseases in the context of integrated herd health programs, using periparturient diseases and traits as an example. Studies, based on 9377 lactations of cows calving in the period 1995 through 1998 from the author's practice in 7 Israeli Holstein herds, show that most periparturient diseases and traits are followed by increased culling, lower production associated with late peaks and lower persistency, and impaired fertility. The effects are independent of other diseases, and at times are long lasting. Production Diseases are often multifactorial and appear at the same stage of lactation. Independent relationships among them must be established, so that common cause effects, direct and indirect causal associations, and incidental relationships can be differentiated. Control of Production Diseases often involves various disciplines and therefore calls for a "multivariate approach". Such an approach, centered on the herd, has led to the adaptation of integrated programs for herd health. The programs are characterized by the adaptation of multidisciplinary, multifactorial, and a population approach to clinical entities. Preventive measures and routine examinations are the hard core of programs, but deeper involvement in nutrition, production and economics is called for. A routine monitoring and causal analysis of periparturient traits and diseases, production, fertility and abortions are carried out, relevant data are processed, and monitoring reports are issued routinely. Five different linear regression models evaluate factors responsible for losses of a) peak milk yield; b) economy corrected (ECM) peak milk yield; c) extended 305-d milk yield; d) daily 3.5\% FCM in the first 90 days in milk; and e) persistencies. Three different logistic and linear regression models evaluate factors that contribute to a) "non pregnancy to first service"; b) unobserved heat; and c) open days. Narrowing down the field of investigation is essential for an intervention to be efficient. Conclusions are drawn from the epidemiological study and the proposed recommendations are weighed with cost/benefit considerations. Possible losses are quantified and used with expected return value in decision analysis. Production Diseases are at times the outcome of managemental mistakes brought about by the drive for higher yields. Integrated herd health programs help to control the negative effects of management by enhancing production under optimal feeding and management regimens. The estimated contribution of improved management to the Israeli national herd phenotypic increase in yield, and the improved fertility that followed the increase in milk yield presented, show that the goal is within reach.
\end{abstract}




\section{Introduction}

The term "Production Diseases" referred traditionally to those diseases induced or exacerbated by management practices, metabolic diseases are typical examples. Factors responsible for ketosis from data of 590 third or more calvers calving in 6 herds through 1996 are presented in Table 1. Heavier cows at drying off, calving in the summer, after a long dry period, suffering from uterine diseases, or being in a negative energy balance (all are risk factors that can be controlled to a degree by better management) were more likely to show clinical ketosis. Recently, the term "Production related diseases" has been enhanced to include other traits, such as infertility, and diseases such as mastitis and lameness, that might involve infectious agents. The author believes that the term "Production Diseases" should apply to all those diseases and traits that are caused or enhanced by nutritional or managemental factors affecting dairy cows' production. The presentation deals with Production Diseases in the context of Integrated Herd Health Programs.

Production Diseases may adversely affect both production and fertility; the two are in many cases interrelated. The following examples illustrate the associations of culling (Table 2), lactation curves (Table 3 ), and fertility indices (Table 4) with postparturient traits and diseases.

\section{Culling and postparturient diseases}

Data are from 2415 lactations of primiparous and 4360 lactations of multiparous cows from the author's practice in 6 Israeli Holstein herds, calving in the period 1995 through 1998. Respective lactational incidence rates for primiand multi-parous cows were $11.9 \%$ and $2.3 \%$ for induction of calving, $6.8 \%$ and $4.8 \%$ for stillbirth, $0.5 \%$ and $0.6 \%$ for prolapsed uteri, $10.0 \%$ and $0.8 \%$ for edema, $1.3 \%$ and $8.9 \%$ for mastitis at calving, $18.4 \%$ and $18.7 \%$ for retained placentae, $35.3 \%$ and $16.4 \%$ for primary metritis, $1.0 \%$ and $1.6 \%$ for left displacement of the abomasum, and $1.5 \%$ and $9.0 \%$ for ketosis. Rates of twins, milk fever, dry-period $<60$ days, and dry-period $>75$ days for multiparous cows were $6.9 \%, 3.6 \%, 18.3 \%$, and $11.1 \%$ respectively. Respective rates of primiparous cows culled before the $1^{\text {st }}$ and before the $6^{\text {th }}$ monthly test days were $5.1 \%$ and $11.2 \%$ for primiparous cows and $7.0 \%$ and $17.2 \%$ for multiparous cows respectively. Crude (for the $6^{\text {th }}$ test day) and summary odds ratios being culled after the various calving diseases and traits are presented in Table 2, increased culling follows most calving diseases and traits. The effects are independent of other diseases (ketosis excluded) and at times long lasting.

\section{Yield and postparturient diseases}

The effects of the various calving diseases on yield and components of the lactation curve in 5974 lactations of cows that had 6 monthly test days are described in Table 3.

Means and SD of peak milk yields, month of

Table 1. Summary of multiple logistic regression analyses for ketosis of 590 third or more calvers in 6 herds, $1996^{\mathrm{a}}$

\begin{tabular}{lccccc}
\hline & $\begin{array}{c}\text { Summer } \\
\text { calvings }\end{array}$ & $\begin{array}{c}\text { Long dry } \\
\text { period }\end{array}$ & $\begin{array}{c}\text { Postparturient } \\
\text { uterine diseases }\end{array}$ & $\begin{array}{c}\text { BCS } \geq 3.75 \text { at } \\
\text { drying off }\end{array}$ & $\begin{array}{c}\text { Milk fat to protein } \\
\text { ratio in 1st test day }\end{array}$ \\
\hline Rate/value & 25.3 & $67.6 \pm 9.1$ & 38.1 & 31.7 & 1.380 \\
Odds ratio $^{\mathrm{d}}$ & $3.2^{* *}$ & $1.3^{* \mathrm{~b}}$ & $7.5^{* *}$ & $2.7^{* *}$ & $2.1^{* *}$ \\
\hline
\end{tabular}

${ }^{*} \mathrm{p}<0.05 * * \mathrm{p}<0.01$; ${ }^{\mathrm{a} E f f e c t s}$ of herds and parity were controlled; ${ }^{\mathrm{b}}$ For each additional 10 days; ${ }^{\mathrm{c} U p p e r}$ quarter; ${ }^{\mathrm{d} O d d s}$ ratio of a cow with a trait having ketosis compared to a cow without one. 
Table 2. Effects of calving diseases and traits on culling variables for 6775 lactations.

\begin{tabular}{|c|c|c|c|c|c|c|}
\hline \multirow{3}{*}{$\begin{array}{l}\text { Culled before: } \\
\text { Odds Ratios: }\end{array}$} & \multicolumn{3}{|c|}{ Primiparous cows $^{\mathrm{a}}$} & \multicolumn{3}{|c|}{ Multiparous cows $^{\mathrm{b}}$} \\
\hline & \multirow{2}{*}{$\begin{array}{l}\text { 1st test day } \\
\text { Adjusted }\end{array}$} & \multicolumn{2}{|c|}{6 th test dayc } & \multirow{2}{*}{$\begin{array}{l}\text { 1st test day } \\
\text { Adjusted }\end{array}$} & \multicolumn{2}{|c|}{ 6th test dayc } \\
\hline & & Crude & Adjusted & & Crude & Adjusted \\
\hline Induction & & & & $2.3 * *$ & & \\
\hline Twins & & & & $1.7 *$ & $1.5^{*}$ & \\
\hline Stillbirth & $3.3 * *$ & $1.7 *$ & $1.8 *$ & & $1.7 * *$ & $1.4 \dagger$ \\
\hline Prolapsed uterus & & & & $10.5 * *$ & $5.9 * *$ & $6.1 * *$ \\
\hline Edema & $0.4 \dagger$ & & & & & \\
\hline Mastitis at calving & $23.3 * *$ & $11.2 * *$ & $12.1 * *$ & $9.4^{* *}$ & $6.0 * *$ & $6.2 * *$ \\
\hline Milk fever & & & & $3.7 * *$ & & \\
\hline Retained placenta & $0.5^{*}$ & & & & $1.3^{*}$ & \\
\hline Primary metritis & $0.5 * *$ & & & & $1.3^{*}$ & \\
\hline Displaced abomasum & & $6.8 * *$ & $7.5^{* *}$ & $3.5^{* *}$ & $4.2 * *$ & $3.5^{* *}$ \\
\hline Ketosis & & $2.5^{*}$ & & & $1.6^{* *}$ & \\
\hline Dry for $<60$ days & & & & & $1.3^{*}$ & $1.2 \dagger$ \\
\hline Dry for $>75$ days & & & & $1.6^{* *}$ & $1.4 * *$ & $1.4^{* *}$ \\
\hline
\end{tabular}

$\dagger \mathrm{p}<1.0{ }^{*} \mathrm{p}<0.05$. ${ }^{* *} \mathrm{p}<0.01$. ${ }^{\mathrm{H}}$ Herd, year of calving, summer and other diseases and traits were included in all models. Herd, year of calving, and summer were included in models of crude odds ratios. ${ }^{b}$ Herd, year of calving, summer, parity and other diseases and traits were included in all models. ${ }^{c} \mathrm{Herd}$, year of calving, summer and parity were included in models of crude odds ratios.

Table 3. Effects of calving diseases and traits on milk yield variables for 5974 lactations ${ }^{\mathrm{a}}$.

\begin{tabular}{|c|c|c|c|c|c|c|c|c|}
\hline \multirow{2}{*}{ Trait or disease } & \multicolumn{2}{|c|}{ Peak yield } & \multicolumn{2}{|c|}{ Month of peak ${ }^{\mathrm{c}}$} & \multicolumn{2}{|c|}{ Persistency $(\%)^{\mathrm{d}}$} & \multicolumn{2}{|c|}{ 305-days yield ${ }^{\mathrm{e}}$} \\
\hline & Milk & ECM & Milk & ECM & Milk & ECM & Milk & $\mathrm{ECM}$ \\
\hline \multicolumn{9}{|c|}{ Primiparous cows (2315 lactations $)^{\mathrm{a}}$} \\
\hline Edema & $1.1 * *$ & $0.9 * *$ & $-0.2 \dagger$ & & & & $213 *$ & $173 *$ \\
\hline Retained placenta & $-0.6^{*}$ & $-0.6^{*}$ & $0.1 \dagger$ & & $-0.6^{*}$ & $-0.9 * *$ & $-161 *$ & $-191 * *$ \\
\hline Primary metritis & & & & & $-0.9 * *$ & $-1.3 * *$ & $-150^{*}$ & $-172 * *$ \\
\hline LDA & & & & & $-0.3^{*}$ & $-3.3^{*}$ & & \\
\hline Ketosis & $2.1^{*}$ & $2.3 *$ & & & & & $479 \dagger$ & \\
\hline \multicolumn{9}{|c|}{ Multiparous cows (3659 lactations) ${ }^{\mathrm{b}}$} \\
\hline Twin & & $0.6 \dagger$ & & & & & & \\
\hline Induction & $-1.3 \dagger$ & $-1.5^{*}$ & & & & & & \\
\hline Stillbirth & $-1.2 *$ & $-0.9 * *$ & & & & & & \\
\hline Mastitis at calving & $-6.9 * *$ & $-5.4 * *$ & $0.5 * *$ & $0.9 * *$ & & $-2.8 * *$ & $-1240 * *$ & $-1248 * *$ \\
\hline Edema & $-2.2 \dagger$ & & & & & & & \\
\hline Retained placenta & $-1.2 * *$ & $-1.0 * *$ & $0.3 * *$ & $0.4 * *$ & $-0.6^{*}$ & $-0.4 \dagger$ & $-136 \dagger$ & \\
\hline Primary metritis & $-1.1^{* *}$ & $-0.8 * *$ & $0.2 * *$ & $0.3 * *$ & $-0.9 * *$ & $-0.8 * *$ & $-243 * *$ & $-184 * *$ \\
\hline LDA & $-4.4^{* *}$ & $-4.0 * *$ & $0.7 * *$ & $0.9 * *$ & $-3.2 * *$ & $-2.8 * *$ & $-821 * *$ & $-731 * *$ \\
\hline Ketosis & & & $0.2 * *$ & $0.2 * *$ & $-0.6 \dagger$ & $-0.6^{*}$ & & \\
\hline
\end{tabular}

$\dagger p<0.1,{ }^{*} p<0.05 . * * p<0.01{ }^{a}$ Effects of herd, year, summer and BCS at calving were included in all models; ${ }^{b}$ Effects of herd, parity, year, summer, BCS at drying off, length of dry period, and changes of BCS at the dry period were included in all models; ${ }^{~}$ Effect of peak yield was also included; ${ }^{~}$ Persistency $=[$ peak yield/180-days yield*100]. Effects of peak yield, month of

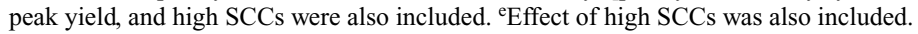


Table 4. The association of fertility indices with calving diseases and traits ( 9377 lactations in 7 herds for cows calving 01/95 through 06/98).

\begin{tabular}{|c|c|c|c|c|c|c|}
\hline $\begin{array}{l}\text { Indice } \\
\text { Trait }\end{array}$ & $\begin{array}{l}\text { Rate } \\
(\%)\end{array}$ & $\begin{array}{c}\text { Unobserved } \\
\text { heat }^{\mathrm{a}}\end{array}$ & $\begin{array}{l}\text { Inactive } \\
\text { ovaries }^{\mathrm{a}}\end{array}$ & $\begin{array}{l}\text { Not pregnant } \\
\text { to first } \mathrm{AI}^{\mathrm{a}}\end{array}$ & $\begin{array}{c}\text { Open } \\
>150 \text { days }^{\mathrm{a}}\end{array}$ & $\begin{array}{c}\text { Rest } \\
\text { Period }^{\mathrm{b}}\end{array}$ \\
\hline \multicolumn{7}{|c|}{ Primiparous cows $(3620 \text { lactations })^{\mathrm{c}}$} \\
\hline Induction of calving & 9.4 & & $0.6^{*}$ & & & \\
\hline Stillbirth & 6.7 & $1.3^{*}$ & & $1.4^{*}$ & $1.4^{*}$ & \\
\hline Prolapsed uteri & 0.4 & & & $4.6^{*}$ & $3.0^{*}$ & \\
\hline Retained placenta & 17.7 & $1.4^{* *}$ & $1.8^{* *}$ & & $1.5^{* *}$ & $2.1 \dagger$ \\
\hline Primary metritis & 31.3 & & $1.5^{* *}$ & & $1.3^{* *}$ & $2.0^{*}$ \\
\hline Mammary edema & 6.9 & & & $0.8 \dagger$ & & \\
\hline \multicolumn{7}{|c|}{ Multiparous cows (5757 lactations) $^{\mathrm{d}}$} \\
\hline Induction of calving & 2.3 & & & & $1.4 \dagger$ & \\
\hline Twins & 6.0 & $1.6^{* *}$ & $2.3^{* *}$ & $1.3^{*}$ & $1.4^{*}$ & $5.0^{* *}$ \\
\hline Milk fever & 1.9 & $0.6^{* *}$ & & $0.7 *$ & & $-5.4 * *$ \\
\hline Prolapsed uteri & 0.3 & $5.3^{* *}$ & $4.6^{* *}$ & & $2.8^{*}$ & \\
\hline Retained placenta & 17.0 & $1.5^{* *}$ & $1.8^{* *}$ & $1.5^{* *}$ & $1.7^{* *}$ & $3.5^{* *}$ \\
\hline Primary metritis & 13.9 & $1.3 * *$ & $1.6^{* *}$ & $1.3 * *$ & $1.4 * *$ & $2.7 * *$ \\
\hline Ketosis & 6.3 & $1.3 \dagger$ & & $1.4^{*}$ & & $3.8^{* *}$ \\
\hline
\end{tabular}

$\dagger \mathrm{p}<0.1 * \mathrm{p}<0.05 * * \mathrm{p}<0.01$; adds ratio suffering from the indice for a cow "with factor" compared to one "without a factor". bestimates of additional days of Rest Period for a cow "with factor". "Effects of herds, years and summer were included. ${ }^{\mathrm{d}}$ Effects of herds, years, parity and summer were included.

peak yield, persistencies, and extended 305-d milk yields were $36.8 \pm 4.8 \mathrm{~kg}$ and $48.7 \pm 6.9$ $\mathrm{kg}, 3.5 \mathrm{~m} \pm 1.3$ months and $2.5 \pm 1.1$ months, $89.4 \% \pm 4.6 \%$ and $86.9 \% \pm 5.6 \%$, and $9511 \pm$ $1341 \mathrm{~kg}$ and $11574 \pm 1837 \mathrm{~kg}$ for 2315 lactations of primiparous and 3659 lactations of multiparous cows respectively. Most calving diseases and traits are associated with lower production, late peak and lower persistency.

\section{Fertility and postparturient diseases}

The relative contributions of calving diseases to fertility indices are presented in Table 4. Data are from 3620 and 5757 lactations of primiparous and multiparous cows respectively, calving in 7 herds in the period 01/95-06/98.

Rates of unobserved heat, inactive ovaries, not pregnant to first service, and open $>150$ days from calving for primiparous and multiparous cows respectively were $35.1 \%$ and $42.9 \%, 8.3 \%$ and $8.8 \%, 55.8 \%$ and $66.1 \%$, and $27.7 \%$ and $29.7 \%$. Mean rest periods were $84.7 \pm 24.7$ days SD and $74.1 \pm 19.7$ days SD for primiparous and multiparous respectively.

Calving diseases and traits are, like most Production Diseases, multifactorial. As all appear in the same stage of lactation, it is desirable that independent interrelationships among their occurrences be established. When independent relationships are established, common cause effects, direct and indirect causal associations, and incidental relationships can be differentiated. The complex associations among the various postparturient diseases in terms of summary odds ratios are presented in Fig. 1 (Markusfeld 1987).

Control of Production Diseases often involves various disciplines and therefore calls for a "multivariate approach". Such an approach, centered on the herd had led to the adaptation of 


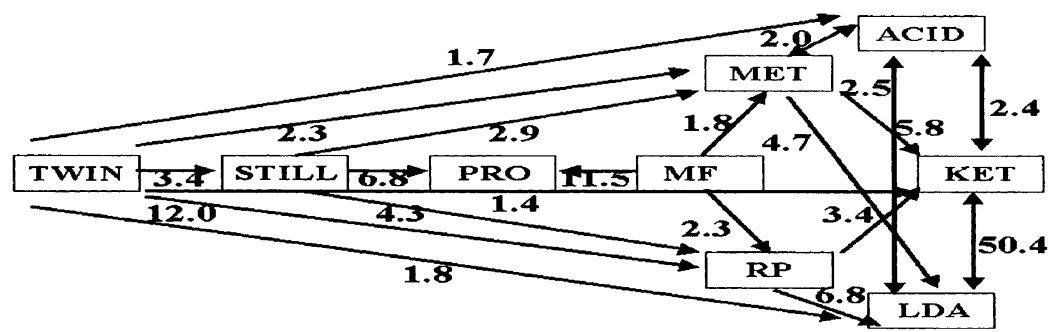

Figure 1. Interrelationships among calving traits in terms of odds ratios (8521 lactations).

integrated programs of herd health. The programs are characterized by multidisciplinary, multifactorial, and with a population approach to clinical entities. Preventive measures and routine examinations are the hard core of programs, but deeper involvement in nutrition, production and economics is called for (Radostits \& Blood 1985). Not losing ground in individual cow medicine when going into herd medicine, application of methods to small and large herds alike, and finally the advancement of techniques and methods serving the new approach comprise some of the difficulties encountered.
Herd health programs should be correctly balanced between individual cow and herd medicine; the main components of the program as practiced by us are outlined in Table 5 .

Some aspects of the program will be presently discussed, the details can be found elsewhere (Markusfeld 1996, Nir-Markusfeld et al. 1998).

\section{Routine diagnostic tests and examinations}

Routine tests allow for a more efficient individual cow therapy through an earlier diagnosis of diseases and their prompt treatment. Clinical diseases are often the observed peaks of more sub-clinical cases that carry similar economic

Table 5. Integrated herd health program.

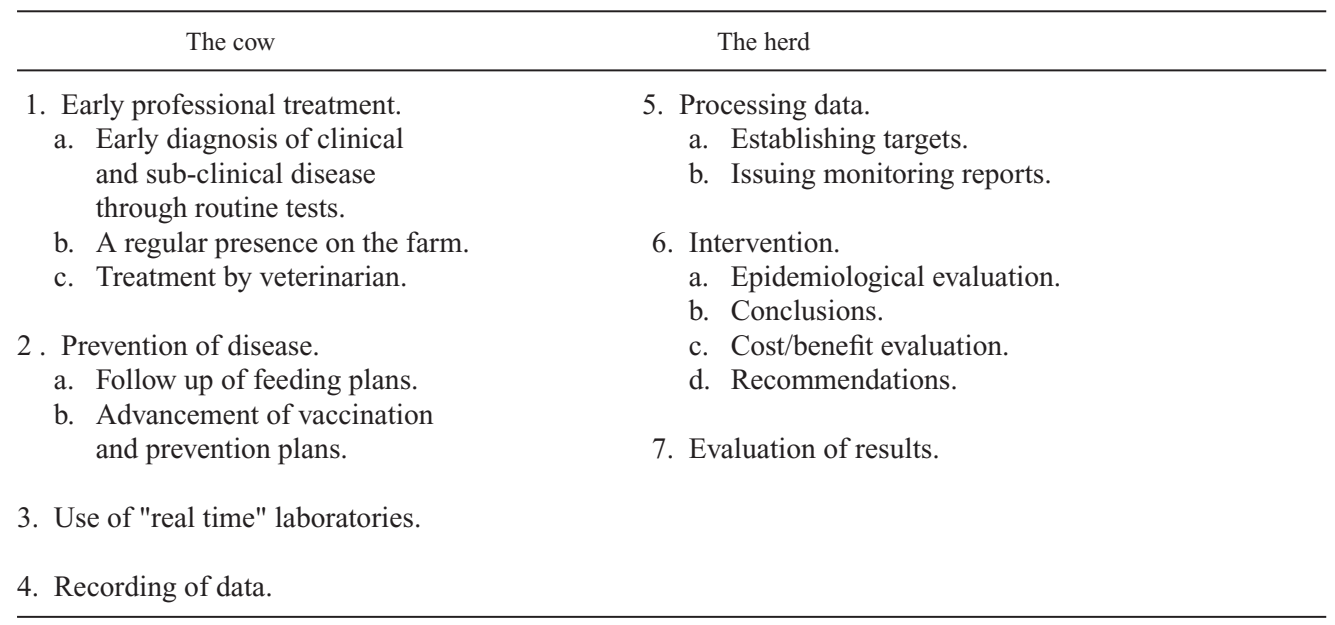


Table 6. Rate of diagnosis of clinical ketosis by a routine urine test compared to diagnosis by herdsmen in 7 herds, from 1982 to 1984.

\begin{tabular}{lrrrrrrrr}
\hline & \multicolumn{8}{c}{ Herd number } \\
\cline { 3 - 8 } & Total & \multicolumn{1}{c}{1} & \multicolumn{1}{c}{ 2 } & 3 & 4 & 5 & 6 & 7 \\
\hline Routine urinalysis (\%) & 15.6 & 13.4 & 15.0 & 18.8 & 10.0 & 19.5 & 30.0 & 10.3 \\
By herdsman (\%) & 4.3 & 0.6 & 2.0 & 7.6 & 6.1 & 5.9 & 7.6 & 1.8 \\
\hline
\end{tabular}

losses (subclinical mastitis and ketosis are wellknown examples). Diagnosis of clinical ketosis by a routine urine test 5 to $12 \mathrm{~d}$ postpartum (Table 6) was more efficient compared to that by herdsmen (Markusfeld-Nir et al. 1984).

Routine examinations also supply the data needed for monitoring and analyzing herd health problems. To be of value, they should be carried out uniformly and at the same stage of lactation. Rate of cows showing heat increases with time from calving as observed from data taken from a herd using pedometers (Fig. 2). Data of unobserved heat could therefore be compared among herds or among individual cows only if they are examined at the same stage of lactation.

\section{Routine tests and examinations}

The routine tests and examinations we recommend to carry out in the dairy herds are:

a. Postparturient examination: 5-12 days postpartum (Metritis, ketosis, LDA) b. Unobserved heat: 50-90 days postpartum. Repeated weekly if necessary.

c. Pregnancy check: Service +40 days and at drying off.

d. Body condition scoring: 5-12 days and 4060 days postpartum, 150 days of gestation and at drying off.

e. CMT and bacteriology of quarters: Annually.

f. Somatic cell counts: Monthly

g. Growth chart of heifers: 3 times a year

The detailed routine activity is described elsewhere (Nir-Markusfeld et al. 1998).

\section{The herd}

To cross the line from individual to herd medicine, data should be recorded and processed, so that both statistical and epidemiological evaluations can be carried out. These relationships should be further explored by causal studies. Herd health monitoring is done on populations, not on individuals. Individual cow

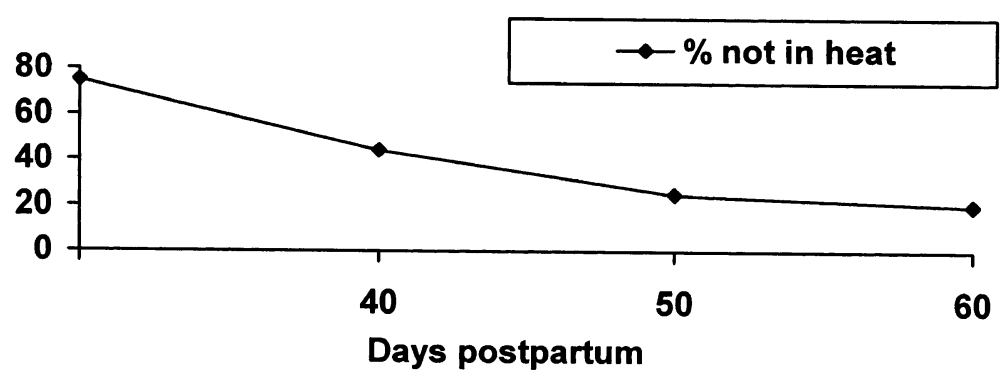

Figure 2. Unobserved heat in 84 multiparous cows. Time from calving to detection of first heat by pedometers. 


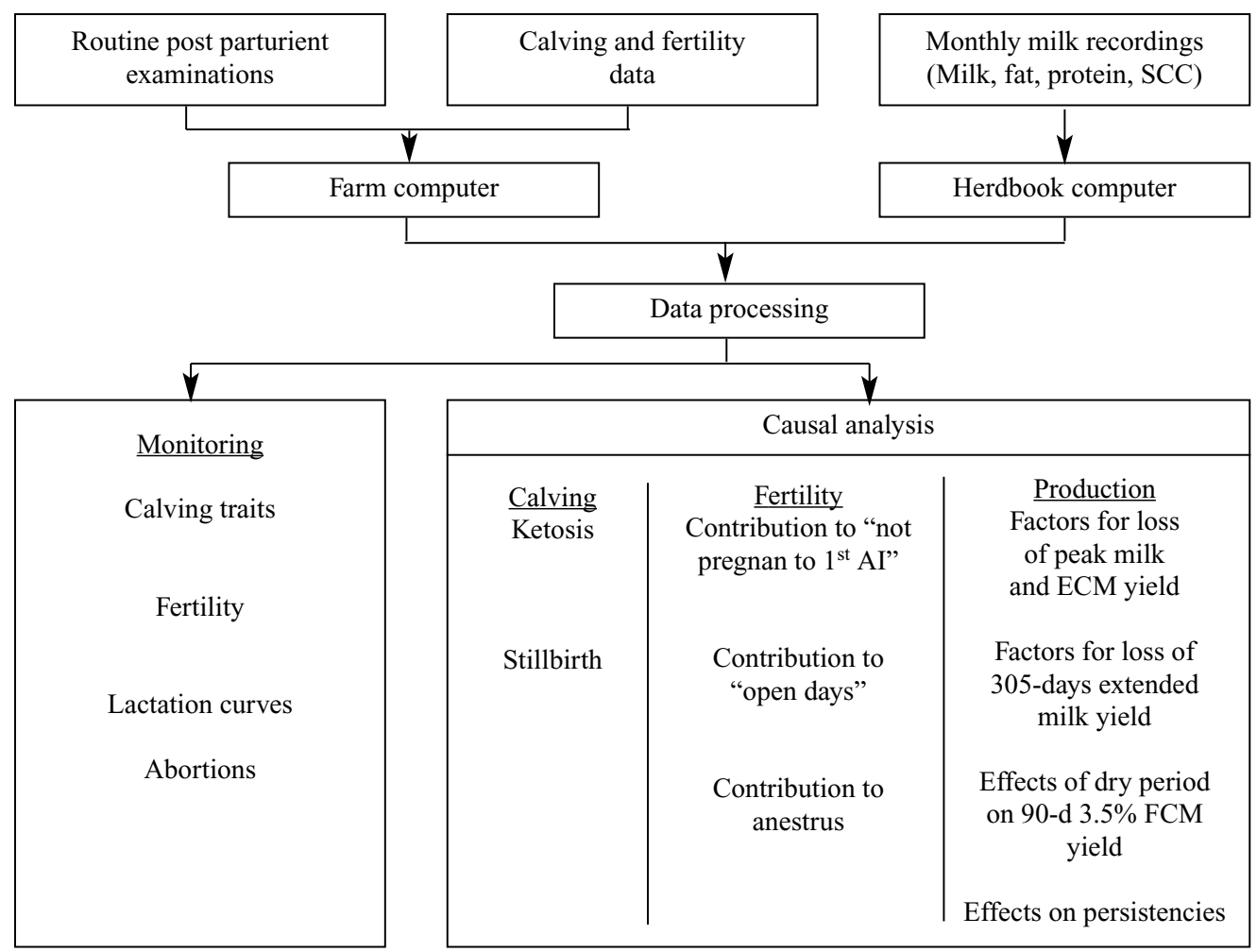

Figure 3. Analysis of Calving $\backslash$ Fertility $\backslash$ Production $\backslash$ Abortions data

data are yet essential if interactions between factors are to be clarified.

\section{Analysis of calving, reproduction, and production data}

A routine monitoring and analysis of health and fertility indices is carried out every 4 months. Relevant data are processed; reports are routinely issued and evaluated (Fig 3).

\section{Monitoring reports}

Integrated computer programs are commonly used. They are designed to provide ongoing monitoring of herd performance that is compared to preset targets of performance (Bartlett et al. 1986). Targets are preset, and are used as a challenge for farmers. Targets should be within reach and updated regularly. We use 2 types of targets in our reports: a) the best quartiles; and b) desired goals. We used targets to influence the length of the dry period in the national herd after routine causal analysis showed that dry periods shorter than 60 days adversely affected production in most herds. Dry periods had become longer after resetting the target for their lower limit from 55 to 60 days in 1993 (Table 7).

We studied the combined effect (interaction) of the length of the dry period and body condition score at drying off on future production (Table 8). Mean 90-days milk, 3.5\% FCM, and 3.0\% PCM yields were $4049 \mathrm{~kg}, 3734 \mathrm{~kg}$, and 3901 
Table 7. Resetting goals for dry periods (15,570 first lactation cows).

\begin{tabular}{lcccc}
\hline Year & 1990 & 1992 & 1994 & 1996 \\
\hline Mean length of dry period, days & 59 & 58 & 62 & 64 \\
\hline
\end{tabular}

Table 8 . Combined effect of the length of the dry period and body condition score at drying off on future production (3659 multiparous cows in 7 herds).

\begin{tabular}{lccc}
\hline Trait/Estimate $^{\mathrm{a}}$ & $\begin{array}{c}\text { 90-days } \\
\text { milk yield }\end{array}$ & $\begin{array}{c}90 \text {-days 3.5\% } \\
\text { FCM yield }\end{array}$ & $\begin{array}{c}90 \text {-days 3.0\% } \\
\text { PCM yield }\end{array}$ \\
\hline BCS at drying off (units) & & $336.4^{*}$ & $183.6^{\dagger}$ \\
Dry period (days) & $13.5^{*}$ & $21.8^{* *}$ & $13.7^{*}$ \\
BCS at drying off*Length of dry period & $-3.4^{\dagger}$ & $-4.6^{*}$ & $-3.7^{*}$ \\
R2 & 0.1720 & 0.1957 & 0.215 \\
\hline
\end{tabular}

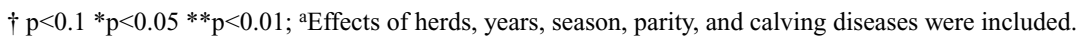

Table. 9. Calving Report 01/09/97-31/08/98.

\begin{tabular}{|c|c|c|c|c|}
\hline \multirow{2}{*}{$\frac{\text { Calving traits }}{\text { a. n Calvings }}$} & \multicolumn{2}{|c|}{ Primiparous cows } & \multicolumn{2}{|c|}{ Multiparous cows } \\
\hline & 100.0 & & 207.0 & \\
\hline b. \% twins & $* 1.0$ & $(0.7)$ & *7.3 & $(5.9)$ \\
\hline c. \% stillbirth & $* 5.7$ & $(5.6)$ & *6.8 & $(5.1)$ \\
\hline d. $\%$ milk fever & 0.0 & $(0.0)$ & *2.8 & $(2.0)$ \\
\hline e. $\%$ prolapsed uterus & $* 1.0$ & $(0.7)$ & 0.5 & $(0.7)$ \\
\hline f. \% displaced abomasum & 0.0 & $(1.0)$ & $(1.0)$ & $(1.5)$ \\
\hline g. $\%$ retained placenta & $* 18.3$ & $(13.3)$ & *25.7 & $(13.1)$ \\
\hline h. $\%$ primary metritis & $* 30.8$ & $(25.0)$ & 16.6 & $(16.6)$ \\
\hline I. \% ketosis & $* 4.2$ & $(1.5)$ & $* 21.0$ & $(6.0)$ \\
\hline j. $\%$ calved with mastitis & 0.0 & $(1.0)$ & 2.2 & $(5.0)$ \\
\hline k. $\%$ daydry $>70 \mathrm{~d}$ & & & $* 23.0$ & $(15.0)$ \\
\hline 1. $\%$ daydry $<60 \mathrm{~d}$ & & & 13.5 & $(15.0)$ \\
\hline m. \% induced calving & $* 18.3$ & $(10.0)$ & 0.6 & $(2.0)$ \\
\hline n. $\%$ calved with edema & $* 21.2$ & $(10.0)$ & 1.7 & $(5.0)$ \\
\hline o. BCS at calving ( $\mathrm{n}$ examined) & 103.0 & & 174.0 & \\
\hline $1 . \%$ with body score $\geq 4.25$ & 7.8 & $(15.0)$ & 5.2 & $(15.0)$ \\
\hline 2. $\%$ with body score $\leq 3.00$ & $* 33.0$ & $(15.0)$ & $* 46.0$ & $(15.0)$ \\
\hline p. BCS changes in dry period ( $\mathrm{n}$ examined) & & & 151.0 & \\
\hline 1. $\%$ lost $\geq 0.5$ units & & & $* 24.5$ & $(15.0)$ \\
\hline 2. $\%$ gained $\geq 0.25$ units & & & 27.8 & \\
\hline
\end{tabular}

Values in parenthesis are targets $*$ denotes values short of targets.

$\mathrm{kg}$ respectively The combined effects of long dry periods and high BCS at drying off resulted in lower production (mainly in terms of fat) independent of the two separate effects. The in- teraction implies that cows with low BCS at drying off will benefit from a longer dry period and vice versa. Drying off according to BCS is therefore now recommended. 
Table 10. Contribution to "Not pregnant to first service" and to "days open"

\begin{tabular}{|c|c|c|c|}
\hline Factor & $\begin{array}{l}\text { Incidence } \\
\text { or quartile }\end{array}$ & $\begin{array}{l}\text { Contribution to non - } \\
\text { pregnancy from } 1^{\text {st }} \mathrm{AI}\end{array}$ & $\begin{array}{c}\text { Open } \\
\text { Days added }\end{array}$ \\
\hline Calving diseases & 38.9 & 6.9 & 5 \\
\hline Unobserved heat & 15.8 & $7.5^{*}$ & $20 *$ \\
\hline Fat/Protein ratio before $\mathrm{AI}^{\mathrm{ac}}$ & 1.110 & $11.2 * *$ & $17^{*}$ \\
\hline Short rest period ${ }^{\mathrm{a}}$ & 75.0 & $10.0 *$ & -7 \\
\hline High yield at drying off ${ }^{\mathrm{ad}}$ & 1563.0 & $-4.2 \dagger$ & $-16^{*}$ \\
\hline Long dry period ${ }^{a}$ & 72.0 & -0.7 & 8 \\
\hline Summer calvings ${ }^{b}$ & 2.0 & -0.6 & -5 \\
\hline Common factors & & $27.0 *$ & \\
\hline Mean days open (151-d upper limit) & & & 117 \\
\hline Rate of non-pregnancy (model) & & 58.2 & \\
\hline Rate of non-pregnancy (actual) & & 52.6 & \\
\hline
\end{tabular}

$\dagger \mathrm{p}<0.1 * \mathrm{p}<0.05 * * \mathrm{p}<0.01 ;{ }^{\mathrm{a}}$ Upper or lower quartile of the lactation group. ${ }^{\mathrm{b}} \mathrm{Calving}$ period April through August; ${ }^{\mathrm{c}} \mathrm{Changing}$ fat/protein ratio; ${ }^{\mathrm{d}} \mathrm{High}$ FCM yield in the last 120 days before calving.

Monitoring reports alert against any fall from preset targets, and as such should be short, concise, engulf all aspects of herd health and issued at regular times (Fetrow et al. 1987). Shortfalls should be further investigated using epidemiological methods. A monitoring report of periparturient traits and diseases is presented in Table 9. We routinely issue reports that deal with calving traits and diseases, reproduction, lactation curves and abortions. The latter also includes a multifactorial analysis that controls the effects of lactation number, trimester of pregnancy, sire and calendar months.

\section{Looking for the "local truth" - epidemiological designs}

Epidemiological evaluations of factors responsible for falls from targets should become a routine. We evaluate the contribution of various factors to lower fertility and milk yield in the individual herds, presenting the results for first, second and third or more lactations' cows in separate sections.

Five different models evaluate factors affecting a) milk; b) economy corrected milk (ECM) peak yields; c) extended 305-d milk yield; d) daily 3.5\% FCM in the first 90 days in milk; and e) persistencies.

Three different models evaluate factors affecting fertility: a) Contribution to "non pregnancy to first service"; b) Contribution to unobserved heat; and c) Contribution to days open. A design that evaluates the contribution of various factors to the indice "Not pregnant to first service" in 95 second lactations' cows is presented in Table 10. Rate of non-pregnancy to first service was $52.6 \%$ (47.4\% pregnancy rate). Mean open days (with an upper limit of 151 days) was 117 days.

Cows presented for unobserved heat, those in a negative energy balance when first inseminated, those dried off with high yield (underconditioned) and those inseminated before 75 DIM contributed $7.5 \%, 11.2 \%,-4.2 \%$ and $10 \%$ respectively to the rate of non-pregnancy.

Steps to improve fertility, aiming at those directions, can now be initiated. When intervention is called for, narrowing down the field of investigation often proves essential if results are to be obtained (Fetrow et al. 1987). This selection process enables the clinician to concentrate efforts and resources, in clinical and laboratory 
Table 11. Fertility indices and various measures of negative energy balance (4510 lactations in 6 herds).

\begin{tabular}{|c|c|c|c|c|c|}
\hline & $\begin{array}{c}\text { Mean } \backslash \\
\text { value }\end{array}$ & $\begin{array}{c}\text { Unobserved } \\
\text { Heat }^{\mathrm{b}}\end{array}$ & $\begin{array}{c}\text { Not } \\
\text { pregnant }\end{array}$ & $\begin{array}{l}\text { Days } \\
\text { Open }^{\mathrm{c}}\end{array}$ & $\begin{array}{c}\text { Rest } \\
\text { Period }^{\mathrm{C}}\end{array}$ \\
\hline Factor $^{\mathrm{a}}$ & & 37.3 & 61.4 & $107 \pm 38$ & $76 \pm 19$ \\
\hline Lost $\geq 0.75 \mathrm{u}$ BCS from calving to AI & 42.9 & $1.23 * *$ & $1.13 \dagger$ & $3.5 * *$ & $1.6^{* *}$ \\
\hline Fat/protein ratio next/preceding $\mathrm{AI}^{\mathrm{d}}$ & 1.08 & $1.24 * *$ & $1.15 \dagger$ & $2.9^{*}$ & $2.1 * *$ \\
\hline Daily FPCM in first 90 DIM $^{\mathrm{d}}$ & 41.1 & & $0.81 *$ & & \\
\hline
\end{tabular}

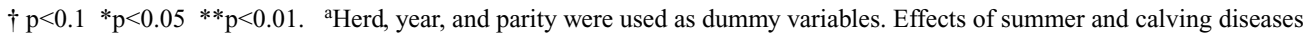

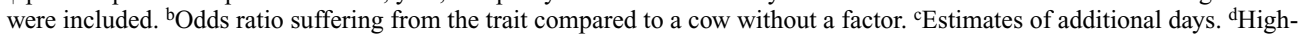
est quarter.

investigations, at most promising directions. In the above example evaluation of dry and fresh cows' rations had been called for.

\section{Improving the analysis by introduction of new variables}

A negative energy balance (NEB) before first service adversely affects fertility, especially in young cows. When we started the routine causal analysis of infertility in the early eighties we used the highest quarters of $3.5 \%$ FCM (average of best 2 out of first 3 milk recordings) as indicators of NEB, assuming that high yielders are in a deeper NEB compared to their lower yielders' counterparts. In 1995 we introduced the loss of BCS from calving to 40 - 60 days in milk, a reflection of fat mobilization (Ferguson \& Chalupa 1989), as a preferable indicator.

Because milk fat concentration tends to increase and milk protein concentration tends to decrease during the postpartum negative bal- ance, Grieve et al. 1986, suggested that fat to protein ratio could indicate lack of energy supply through feed. Heuer et al. 1999, evaluated similar associations in data derived from regular milk control. Data of BCS are not always available; we use now routinely the changing of fat to protein ratios as a measure of NEB in the models. Calculation is done in the following way: a) Fat percentage/Protein percentage is calculated for each test day; b) the changing ratios are then calculated and the value of the upper quartile is obtained for the different lactations.

Fat to protein ratio $=($ fat $/$ protein in test day following AI / fat / protein in test day preceding $\mathrm{AI}$ )

We evaluated the association between some fertility indices and the 3 variables used to indicate NEB before AI using data derived from 4510

Table 12. Incomplete hypothetical data in second lactations' cows. Estimates of changes in peak milk yield (kg).

\begin{tabular}{|c|c|c|c|c|}
\hline & \multicolumn{2}{|c|}{ Complete data } & \multicolumn{2}{|c|}{ Partial data ${ }^{\mathrm{a}}$} \\
\hline & Incidence or quartile & Milk changes & Incidence or quartile & Milk changes \\
\hline Calving diseases & 37.1 & $-2.2 *$ & 10.3 & $4.0 *$ \\
\hline Summer calvings ${ }^{b}$ & 35.1 & $-2.8 *$ & 35.1 & $-2.3 *$ \\
\hline Low BCS at calving ${ }^{c}$ & 3.00 & 0.7 & 3.00 & -0.2 \\
\hline Short dry periodc & 61.0 & $-3.0 *$ & 61.0 & $-3.9 * *$ \\
\hline
\end{tabular}

${ }^{*} \mathrm{p}<0.05 * * \mathrm{p}<0.01 ;{ }^{\mathrm{a}}$ Not all cases of metritis are included; ${ }^{\mathrm{b}}$ Calving period April through August; ${ }^{\mathrm{c}}$ Lowest quarter. 


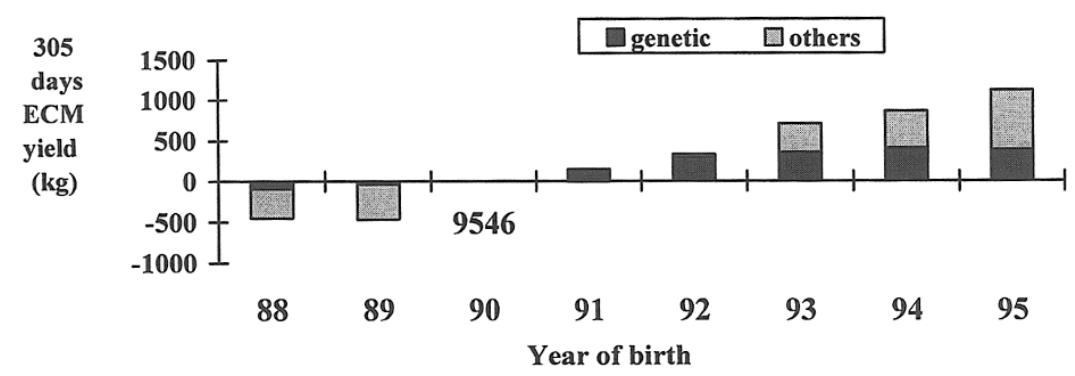

Figure 4. Israeli Holstein - Phenotypic increase of economy corrected milk (ECM) according to year of birth (Ezra 1998)

lactations in 6 herds calving in the period 01/95-05/98 to (Table 11 ).

Using loss of 0.75 units BCS from calving to AI as standard, the sensitivity and specificity of the fat to protein ratio were $22.9 \%$ and $73.7 \%$ respectively.

\section{Data analysis and quality of the data}

Advanced statistical methods could not take the place of complete and reliable data as illustrated in Table 12. In the hypothetical example the various contributions of metritis to "loss in peak yield" are illustrated. When not all cases of metritis were diagnosed ("partial data"), cows with metritis produced more milk than cows without the factor.

\section{Conclusions}

Production Diseases are at times the results of managemental mistakes, but often a necessary outcome of modern dairy industry that is pushing for maximization of profit. Integrated herd health programs help to control the negative effects of management by enhancing production under optimal feeding and management regimens. Fig. 4 (Ezra 1988) describes the relative contributions of genetic and managemental components to the phenotypic increase in ECM in Israeli Holsteins (reference year of birth is 1990). Fig. 5 compares the overall conception rates in multiparous cows to annual ECM production in reference years. The data taken from the Israeli Holstein Herdbook and representing about $85 \%$ of the national herd show that the goal is within reach.
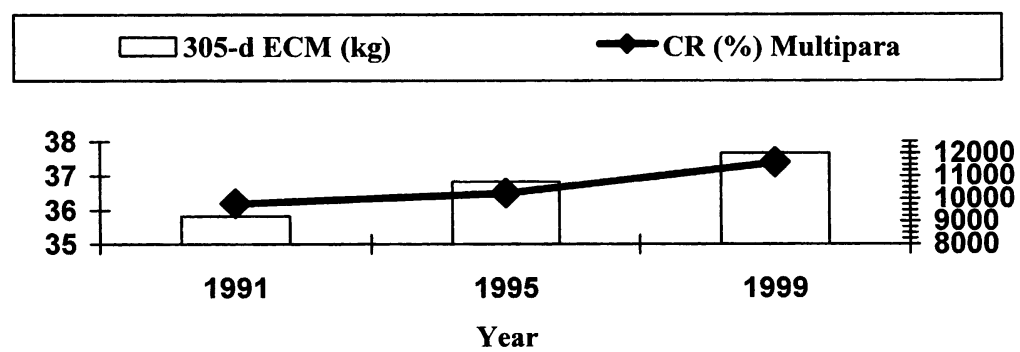

Figure 5. Comparison of annual economy corrected milk (ECM) production and overall conception rates in multiparous cows in reference years (Israeli Herdbook reports 1991, 1995, and 1999). 


\section{References}

Bartlett PC, Kaneene JB, Kirk JH, Wilke MA, Martenuik JV: Development of a computerized dairy herd heath database for epidemiological research. Prev Vet Med 1986, 4, 3-14.

Ezra E: Personal communication 1998.

Ferguson JD, Chalupa, W: Symposium: Interactions of nutrition and reproduction. Impact of protein nutrition on reproduction in dairy cows. J dairy Sci 1989, 72, 746-766.

Fetrow J, Harrington B, Henry ET, Anderson, KL: Dairy herd health monitoring. Part I. Description of monitoring systems and sources of data. Comp Food Animal 1987, 9, F389-F398.

Grieve DG, Korver S, Rijpkema YS, Hof G: Relationship between milk composition and some nutritional parameters in early lactation. Livestock Production Sci. 1986, 14, 239-254.

Heuer C, Schukken YH, Dobbelaar P: Postpartum body condition score and results from the first test day milk as predictors of disease, fertility, yield, and culling in commercial dairy herds. $\mathbf{J}$ Dairy Sci 1999, 82, 295-304.

Israel Cattle Breeders Association. Israel Holstein Herdbook 1991, 1995, 1999. P.O.Box 3015.
Markusfeld (Nir) O, Nahari N, Adler H: Evaluation of a routine testing for ketonuria and aciduria in detection of sub and clinical ketosis associated with overfeeding in dairy cattle. The Bovine Practitioner 1984, 219-222.

Markusfeld $O$ : Periparturient traits in seven high yielding dairy herds. Incidence rates, association with parity, and interrelationships among traits. J. Dairy Sci. 1987, 70, 158-166.

Markusfeld-Nir O: Integrated herd health programs the Israeli experience. Proceedings of the meeting 27th-29th of March 1996 of The Society for Veterinary Epidemiology and Preventive Medicine. Glasgow. Ed. M.V. Thrusfield \& E.A. Goodall. pp 126-135.

Nir (Markusfeld) O, Enevoldsen C, Kroll O: Herd Health - I. 1998. Ruppin Institute for Higher Education.

Radostits OM, Blood DC: Herd Health. A Textbook of Health and Production Management of Agricultural Animals. W.B. Saunders Company, Philadelphia. 1985, 48.

Peer reviewed contribution to 11. International Conference on Production Diseases in Farm Animals, 12-16 August 2001, KVL, Frederiksberg, Denmark.

Reprints may be obtained from: Oded Nir (Markusfeld), Veterinary Services and Animal Health, Ministry of Agriculture, Israel. E-mail: cvo_vsah@moag.gov.il, fax: 972-3-9681641. 